\title{
'svacittamâtra' The Basic Standpoint of the Lankâvatâra sûtra
}

\section{Gishin Tokiwa}

\section{I. 'sva-citta-mâtrah', the Standpoint of the Lankâvatâra sûtra}

Although the Lankâvatâra sûtra (represented below as the Lainkâ) deals with a great variety of subjects, it seems to make it its own central theme and standpoint that man realize the reality of 'sva-citta-dṛ́sya-mâtra'. The sutra states :

yathâbhûtâvasthâna-darśanaṃ mahâmate sarvadharmânâm yaduta sva-cittadṛśya-mâtrâvatârah. (Vaidya ed. 46, Nanjo 112) (By "the ultimate perception of everything that has its own form abiding in its true mode of being" I mean the realization that what appears as external to us is nothing other than our own mind.)

The term 'citta-mâtra', as is well-known, appears in the Daśabhûmika sûtra (at the sixth stage of bodhisattva-practice, V 32, Rahder 49):

citta-mâtram idam yad idam traidhâtukam. (This is nothing but the mindthis very tripleworld.)

The Laìkâ has expressions such as:

svacitta-mâtram-idaṃ traidhâtukam-âtmâtmîya-rahitam (V 34, N 80). *a traidhâtuka-svacittatayâdhimuktitạ (V 19, N 42).

What deserves attention here is that the Lanka has the expression 'sva-cittamâtra' as well as 'citta-mâtra', and that the sutra seems to place more significance on the former than on the latter.

The term 'sva-citta-mâtra', which literally means 'nothing but one's own mind', according to the quotation $*_{a}$ above, means more than that; it signifies the Self that is free from the ego and the object of the ego, the Self without any form even of the mind.

Here it must be noted that by 'citta-mâtra', the Laika never asserts the ultimate existence of citta; rather the term indicates the true mode of being 
(35) 'svacittamâtra' The Basic Standpoint of the Laṅkâvatâra sûtra (G. Tokiwa) which is free from being and non-being, that is, that which is free from the very mind that manifests itself as being and non-being. The verse below states this point very clearly:

na bhâvaṃ nâpi câbhâvạ̣ bhâvâbhâva-vivarjitam;

tathatâ citta-vinirmuktam citta-mâtram vadâmy-aham (k $30 \mathrm{~V} \mathrm{63,} \mathrm{N} \mathrm{153).}$

By adding 'sva' to 'citta-mâtra', the Lainka does not alter this point- that is, that the delusive manifestation is not final and that the true mode of being which is said to be 'citta-mâtra' is free even from the subjectivity of 'citta' - ; it goes on to elucidate that this manifestation-no-manifestation is a matter of the fundamental subject of history itself, rather than being anything objective or external to that subject. No wonder we have the expression,

svacitta-nirâbhâsa-mâtrâvatâreṇa prajñâ-pâramitâ-vihârânuprâptâ (V 19, N 42). (Through attaining the reality as nothing but our own mind, which is the Self free from manifestation, we return to abiding in the final attainment of prajñâ.)

So far as the Yogâcâra viewpoint of this sutra is concerned, the concept of 'sva-citta-mâtra' as is interpreted here appears to be deeply related to that of 'tri-svabhâva', (i. e., the threefold mode of being of the self-same reality; parikalpita-, paratantra-, and parinișpanna-svabhâva). Because of the ultimacy of the 'sva' or Self, 'citta' or mind as the principle of delusion is seen through and overcome immediately here and now. The immediate overcoming of the principle of delusion through the attainment of the Self without form is elucidated in the sutra as follows.

svacitta-dṛ́sya-dhârâṃ yugapat-tathâgataḥ sarva-sattvânâm viśodhayati nirvikalpâm nirâbhâsa-gocarâm (V 24, N 55-56). (Every being's own mind is purified by the tathâgata of its continuous false manifestation immediately here and now because their true Self is free from discrimination and manifestation.)

In this as well as some other important points, by the way, the Lainkâ reflects its author's intimate knowledge of the Vajra-cchedikâ prajñâ-pâramitâ sûtra. The above quotation from the Lank $\hat{a}$ reminds us of the well-known passage from the Vajracchedika (18):

bhagavân-âha—yâvantạ̣ subhûte teșu lokadhâtuṣu sattvâh, teșâm-aham nânâbhâvâm citta-dhârâm prajânâmi. tat-kasya hetọ̣ ? citta-dhârâ citta-dhârâ- 
'svacittamâtra' The Basic Standpoint of the Lankấvatâra sûtra (G. Tokiwa)

iti subhûte adhârâ-eșâ—atîtạ̣ subhûte cittạ̣ nôpalabhyate; anâgatam cittạ̣ nôpalabhyate; pratyutpannam cittạ̣ nôpalabhyate.

\section{The True Continuity of svacitta-mâtra}

As the Vajracchedikâ puts it, svacitta-driśya-dhârâ or the continuous false manifestation of our own mind is really 'adhârâ', that is, free from continuity, so that one cannot perceive the past mind, the future mind, or the present mind. The sutra says that this no-perception of the threefold mind is the true knowledge of continuity. This means that no continuity is true continuity. This is a very difficult but important point.

The Lankâ mentions the three characteristics of vijñâna: pravṛtti-, karma-, and svajâti-lakșanam. The karma nature of vijñâna, as the source of its pravṛtti aspect, constitutes the apparent continuity (prabandha) of false manifestation both temporal and spatial. The sutra states,

prabandha-[utpâda-sthiti-] nirodhaḥ...yasmâc-ca pravartate. yasmâd-iti...yadâśrayeṇa yad-âlambanena ca. tatra yad-âśrayam-anâdikâla-prapañca-daușthulya-vâsanâ. yad-âlambanaṃ svacitta-dṛ́śya-vijñâna-vișaye vikalpâh (V 18, N 38).

But the svajâti or original nature of vijñâna is free from the continuity of arising, abiding, and cessation. This No-continuity of the original nature of vijñâna, (that is, of dharmakâya,) is the very ground (âlayavijñâna) upon which continuous false manifestation takes place only because the original nature is not awakened to. It is for this reason that in this sutra âlayavijñâna, the ground for false manifestation, is identified as dharmakâya (V 20, N 44). Delusion ceases to manifest itself when delusion is realized as such. A Chinese Zen master (Ch'ang-sha Ching-ts'en: Choshha Keijin, 8-9th c. A. D.), who is recorded to have said,

"No one person in any of the ten directions of the world is anthing but me (Ching-te Ch'uan-teng lu 10)."

made these remarks in response to an inquiring monk (Chodang chip 17):

Hao-yüeh said, "What do you mean by 'originally void'?"

The master said, "I mean karma-hindrance."

"What do you mean by 'karma-hindrance'?"

The master said, "I mean originally void." 
(37) 'svacittamâtra' The Basic Standpoint of the Lañkâvatâra sûtra (G. Tokiwa)

Hao-yüeh expressed his deep thanks.

Our problem is, then, on the basis established above, how to consider the creation of history.

\section{III. 'svacitta-utpâdah', the Principle of the Creation of History}

The creation of history is made possible only by the fundamental subject of history that has overcome and is free from attachment to the delusive manifestations such as the subjective agent and the objective world. Otherwise even the mere raising of a single hand, in so far as it is rooted in the irretrievable discrimination of the self and the world, is just so much contamination of history. The Lainkâ has this expression:

nirâbhâsa-gocaram-utpâda-sthiti-bhanga-varjyaṃ svacitta-utpâda-anugatam vibhâvayiṣyanti...bodhisattvâḥ mahâsattvâh (V 19, N 42). (Great beings whose fundamental subject is Awakening should practice No-manifestation in which arising, abiding, and cessation are overcome and which is followed by the making up of their own mind.)

This immediately reminds us of the familiar expression in the Vajracchedika, ‘cittam-utpâdayitavyam' in passages such as :

i. tasmât-tarhi subhûte bodhisattvena mahâsattvena sarva-sṃjñâ vivarjayitvâ anuttarâyâm samyaksaṃbodhau cittam-utpâdayitavyam. na rûpa-pratiṣțitam cittam-utpâdayitavyam...na kvacit-pratișthitam cittam-utpâdayitavyam...apratiṣțhitena bodhisattvena dânạ̣ dâtavyam (14).

In this passage, the 'cittôtpâda' or determination, of almsgiving takes place in nowhere else than the utimate Awakening itself, so that it may be free from abiding in and attachment to anything whatever.

ii. subhûte bodhisattva-yâna-samprasthitena evaṃ cittam-utpâdayitavyamsarve sattvâ mayâ anupadhiśeșe nirvâṇa-dhâtau parinirvâpayitavyâh. evaṃ ca sattvân parinirvâpya na kaścit-sattvaḥ parinirvâpito bhavati (17 \& 3).

Here this determination is said to take place so that all beings whose ground is originally complete nirvâna may be awakened to that ground as their fundamental subjectivity.

Returning to the Lainkâ, we have seen that emphasis is put on the concept of 'sva' so as to prepare the way for considering the fundamental subject of 
'svacittamâtra' The Basic Standpoint of the Lañkâvatâra sûtra (G. Tokiwa)

history. Creating history is the work of this fundamental subject who has overcome the basic dilemma of history through his awakening to the Self without form. No dilemma or contradiction of history remains external to him or prevents him from freely forming history, because he is the depth (religion) himself, and therefore is the whole extension of space (the world) and the whole length of time (history) himself as well. This seems to be what is meant by the title of this sutra, "entering (or attaining) Lankâ". Lañkâ here means the historical world whose fundamental subject is awakened to the Self without form. Based on this viewpoint, it seems to me, the sutra takes up the pessimistic quietism of (Sâmkhya's) abhivyakti view and the optimistic rationalism (of Nyâya-Vaiśeșika).

\section{Criticism of Erroneous Views on the World and History}

According to the Lainkâ, erroneous views concerning the world and history (tîrthakara-vâda-kudrșți) are a consequence of the failure to realize that what appears as external is nothing but one's own mind (svacitta-mâtrânavatârena. V $19, \mathrm{~N} 40$ ). Conversely, this means that the world is mistakenly viewed to exist outside, so that history is considered as either proceeding from what is to what is not, or as being built up from what is not to what is.

In (Sâmkhya's) abhivyakti view, some substance (dravya) as the cause of the world manifests itself through time, and the manifestations thus arise, abide, and disappear. This process goes on outside the observer, who sees everything culminating in destruction and who neither desires nor knows how to particicipate in the process. His only recourse is to try to detach himself from it. The sutra says this is an annihilistic view which utterly removes continuity, action, arising, breaking, being, nirvâna, the way leading to nirvâna, karma, its fruition, and truth (ibid.). The sutra criticizes this, and says that in not having realized that what appears as external is merely one's own mind discriminated as such, one fails to see the uninterrupted occurrence of disappearance. The implication is that in disappearance one should see nothing other than one's own mind, which is free from not only disappearance but appearance as well.

The rational optimism (of Nyâya-Vaiśeșika) begins where the former nihilistic view ends. In other words, in the midst of mere non-being, being is introduced 
(39) 'svacittamâtra' The Basic Standpoint of the Laṅkâvatâra sûtra (G. Tokiwa) when the three conditions_-kriyâ (action), karma (the object of action), and karana (the means of action)_combine to work. In this view, effect always follows cause, and there cannot be any miscalculation regarding causal relations. Wherever there is a combination of the three conditions, they believe that significant change takes place. Such a view appears to result in a very active commitment to the formation of history. Nevertheless, the sutra criticizes this too, commenting as follows.

vijñânânâṃ tri-samigati-pratyaya-kriyâ-yogena-utpattir-abhavișat, asatâm-api mahâmate kûrma-romnâm-utpattir-abhavișyat, sikatâbhyo vâ tailasya. pratijñâhânir-niyama-nirodhaś-ca mahâmate prasajyate, kriyâ-karma-karạ̣a-vaiyarthyam ca sad-asato bruvatah (V 19, N 41).

(Should the three conditions of perception gather to make things arise, there would be bristles growing on a tortoise or oil from stones. This is followed by the abandonment of propositions and the negation of fixed rules. For these abvocates of this view, which attaches itself to being and non-being, action, the object of action, and the means of action, i. e. the the three conditions become useless.)

What is wrong with this latter view, which appears applicable to the modern world, lies in taking what appears as external merely as such, however active the commitment may be in making things arise.

According to the sutra, these two viewpoints, a pessimistic quietism and an apparently optimistic rationalism, are the outgrowth of a lack of confidence (śraddhâ) in the true sense of the term. Confidence obtains in freedom from the personal and historical dilemma in which man finds himself; that is, the dilemma of oneness and difference, being and non-being, etc. The Laink $\hat{a} s$ consistent elucidation of 'sva-citta-mâtra' presents to us the method by which to attain, and the content of, this freedom and confidence. 